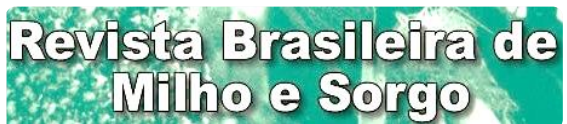

Brazilian Journal of Maize and Sorghum

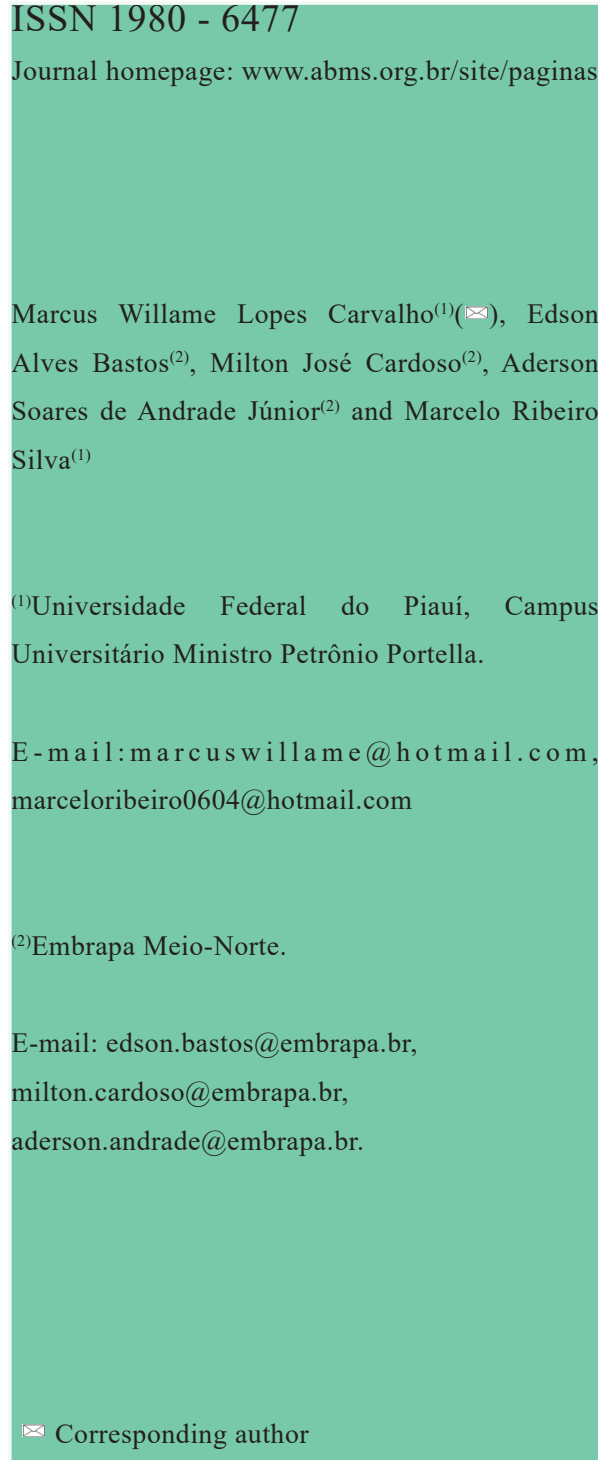

$\bowtie$ Corresponding author

How to cite

CARVALHO, M. W. L.; BASTOS, E. A. CARDOSO, M. J.; ANDRADE JÚNIOR, A. S. SILVA, M. R. Productive performance of maize crop irrigated with and without water deficit in different plant arrangements. Revista Brasileira de Milho e Sorgo, v. 19, e1196, 2020.

\section{PRODUCTIVE PERFORMANCE OF MAIZE CROP IRRIGATED WITH AND WITHOUT WATER DEFICIT IN DIFFERENT PLANT} ARRANGEMENTS

\begin{abstract}
The objective of the present study was to evaluate the effects of row spacing and planting density, under different water regimes, on dry grain production of the maize hybrid AG -1051, in Teresina, Piauí. Two experiments were conducted with the use of a conventional sprinkler system for irrigation, being one with $100 \%$ and the other with $50 \%$ crop evapotranspiration (ETc) replacement. A randomized block experimental design was used, in a $5 \times 2$ factorial scheme, combining five planting densities (PD) (20,000; 40,000; 60,000; 80,000; and 100,000 plants $\mathrm{ha}^{-1}$ ) and two spacings between rows (RS) $(0.5$ and $1.0 \mathrm{~m})$, with four replications. The weight of 100 grains, cob percentage, grain yield, and water use efficiency were evaluated. The increment of planting density caused a linear decrease in the 100-grain weight and increment of the cob percentage in relation to the total ear weight. Under full irrigation regime, the combination of the $0.5 \mathrm{~m}$ row spacing and planting density of 72,000 plants ha ${ }^{-1}$ provided maximum yield of $7.2 \mathrm{Mg}$ $\mathrm{ha}^{-1}$. Under water deficit condition, the maximum yield of $4.8 \mathrm{Mg} \mathrm{ha}^{-1}$ was reached in the combination of the $0.5 \mathrm{~m}$ row spacing and planting density of 67,000 plants ha ${ }^{-1}$. The total water depth of $419 \mathrm{~mm}$ provided maximum WUE of $1.70 \mathrm{~kg} \mathrm{~m}^{-3}$. The total water depth of $268 \mathrm{~mm}$ caused a reduction in WUE with maximum point of $1.54 \mathrm{~kg} \mathrm{~m}^{-3}$.
\end{abstract} Keywords: Zea mays L., plant density, row spacing, water deficit.

\section{DESEMPENHO PRODUTIVO DO MILHO IRRIGADO COM E SEM DÉFICIT SOB DIFERENTES ARRANJOS DE PLANTAS}

Resumo - O objetivo do presente estudo foi avaliar os espaçamentos entre linhas de cultivo e densidade de semeadura sob diferentes regimes hídricos na produção de grãos secos do híbrido de milho AG -1051, em Teresina, Piauí. Conduziram-se dois ensaios irrigados por aspersão convencional, com $100 \%$ e $50 \%$ de reposição da evapotranspiração da cultura (ETc). Utilizou-se o delineamento experimental de blocos casualizados com esquema fatorial $5 \times 2$, combinando-se cinco densidades de plantio (DP) $\left(20.000 ; 40.000 ; 60.000 ; 80.000\right.$ e 100.000 plantas ha $\left.^{-1}\right)$, dois espaçamentos entre fileiras (EEL) (0,5 e 1,0 m), com quatro repetições. Avaliou-se o peso de 100 grãos, percentual de sabugo, produtividade de grãos e eficiência no uso da água. $\mathrm{O}$ incremento na densidade de plantio proporcionou decréscimo linear do peso de 100 grãos e incremento na porcentagem de sabugo em relação ao peso total de espigas. Em regime com irrigação plena, a combinação entre o EEL 0,5 e a DP de 72.000 plantas ha proporcionaram produtividade máxima de $7,2 \mathrm{Mg} \mathrm{ha}^{-1}$. Em condição de déficit a produtividade máxima de $4,8 \mathrm{Mg} \mathrm{ha}^{-1}$ foi atingida na combinação do EEL de 0,5 m e DP de 67.000 plantas ha $^{-1}$. A lâmina total de $419 \mathrm{~mm}$ proporcionou EUA máxima de 1,70 $\mathrm{kg} \mathrm{m}^{-3}$. A lâmina total de $268 \mathrm{~mm}$ reduziu a EUA com ponto máximo para $1,54 \mathrm{~kg} \mathrm{~m}^{-3}$. Palavras-chave: Zea mays L., densidade de plantas, espaçamento entre fileiras, déficit hídrico. 
Maize (Zea mays L.) is one of the world's most widely cultivated cereal grains and Brazil is the third largest producer after the United States and China (Cunha et al., 2019). In Brazil, the maize production reached 100 million tons in the 2018/2019 crop season, in a cultivated area of 17.49 million hectares, with average grain yield of $5.71 \mathrm{Mg} \mathrm{ha}^{-1}$ (CONAB, 2019). However, according to data provided by the USDA (2020), Brazil presents yield below the global average (5.86 $\mathrm{Mg} \mathrm{ha}^{-1}$ ) and half the average yield of the United States $\left(11.07 \mathrm{Mg} \mathrm{ha}^{-1}\right)$, which are benefited by the weather conditions.

Among the management techniques, the specification of appropriate spacing and plant density may impact crop yield. When assessing the maize response to the increment of plant density, in different spacing between rows, Sangoi et al. (2019) observed that densities of 9 and 11 plants $\mathrm{m}^{-2}$ and reduced row spacing of $0.40 \mathrm{~m}$ represented management strategies to optimize grain yield. According to Murányi (2015), the increase of plant density above a certain limit reduces the individual plant production and increases the yield per area unit.

Other factors that compromise production and contribute to low yield are the lack of genotypes that are more tolerant to water deficit and the non-uniformity of precipitations, with the occurrence of Indian summers, often lasting for a long period, during the critical stage of crop growth (Sousa et al., 2015). Water deficit impacts the water relations of the plant, reducing growth, development, and consequently productivity of the crop (Sales et al., 2016). In addition, it can shorten the grain formation period and reduce the ovary growth and development, thus increasing the number of aborted grains (Marwein et al., 2017).

For the Middle-North Region of Brazil, there is still little information concerning the specification of a proper plant arrangement for the commercial maize hybrid AG-1051, with different irrigation depths, especially under water deficit conditions. Ben et al. (2016) assessed the effect of different irrigation depths and plant densities on maize crop, in the municipality of Alegrete, state of Rio Grande do Sul, which presented higher grain yield of $15.25 \mathrm{t} \mathrm{ha}^{-1}$ at a density of 130 thousand plants $\mathrm{ha}^{-1}$, with irrigation depth of $100 \%$ of ETc.

In this context, the adequacy of plant density in different irrigation scenarios is a way to maximize the absorption of soil water and nutrients, and consequently crop productivity. Therefore, the objective of the present study was to evaluate the effect of planting row spacing and planting density, under different water regimes, on yield components and dry grain production of the double-cross maize hybrid AG - 1051, in the municipality of Teresina, state of Piauí.

\section{Material and Methods}

Two experiments were conducted in the experimental area of Embrapa Meio-Norte, located in Teresina, Piauí ( $5^{\circ} 05^{\prime} \mathrm{S}, 42^{\circ} 29^{\prime} \mathrm{W}$ and altitude of $72 \mathrm{~m}$ ), from September to December 
2018. According to the climate classification of Thornthwaite \& Mather (1955), the climate in the municipality is $\mathrm{C} 1 \mathrm{sA}$ ' a' type, characterized as dry sub-humid, megathermal, with moderate water surplus in the summer. It presents average annual temperatures of $28.2{ }^{\circ} \mathrm{C}$, maximum of $34^{\circ} \mathrm{C}$ and minimum of $22.6{ }^{\circ} \mathrm{C}$, average relative humidity of $69.5 \%$ and average rainfall of $1,330.8 \mathrm{~mm}$ per year (Bastos \& Andrade Júnior, 2019). The soil in the experimental area is classified as Eutrophic Fluvic Neosol (Melo et al., 2014).

Soil preparation consisted of plowing and harrowing. Fertilization was performed based on soil physical and chemical analysis and recommendation for the crop in the region (Cardoso et al., 2011). For the basal dressing, 75 $\mathrm{kg}$ of $\mathrm{N} \mathrm{ha}^{-1}, 70 \mathrm{~kg}$ of $\mathrm{P}_{2} \mathrm{O}_{5}$ ha $^{-1}$ and $60 \mathrm{~kg}$ of $\mathrm{K}_{2} \mathrm{O}$ $\mathrm{ha}^{-1}$ were applied in $0.08 \mathrm{~m}$-deep furrows.

Seeds of the commercial maize hybrid AG-1051 were manually sown on the $11^{\text {th }}$ of September 2018, in the amount of two seeds per hole.

Top dressing was carried out when the plants presented the sixth leaf fully expanded, with application of $45 \mathrm{~kg}$ of $\mathrm{N} \mathrm{ha}^{-1}$. For the fertilizations, ammonium sulfate, triple superphosphate and potassium chloride were used as sources of $\mathrm{N}, \mathrm{P}_{2} \mathrm{O}_{5}$ and $\mathrm{K}_{2} \mathrm{O}$, respectively.

Preventive weed control was implemented with the application of pre-emergence herbicides, using a mixture of atrazine and S-metolachlor $\left(1,480+1,160 \mathrm{~g}\right.$ a.i. ha $\left.{ }^{-1}\right)$. When the plants were in the V3 growth stage, weed control was supplemented with the application of tembotrione herbicide (100.8 g a.i. ha $\left.{ }^{-1}\right)$. Control of fall armyworm (Spodoptera frugiperda) was carried out with the application of lufenuron insecticide $\left(15\right.$ g a.i. ha $\left.{ }^{-1}\right)$.

A fixed conventional sprinkler irrigation system was used, equipped with impact sprinklers with $4.4 \times 3.2 \mathrm{~mm}$ nozzles, spaced $12 \times 12 \mathrm{~m}$ apart, with flow rate of $1.59 \mathrm{~m}^{-3} \mathrm{~h}^{-1}$, operating pressure of $30 \mathrm{mca}$, and water application intensity of $11.04 \mathrm{~mm} \mathrm{~h}^{-1}$.

Crop evapotranspiration (ETc) was calculated by the product of the reference evapotranspiration (ETo) and the crop coefficient (Kc), according to Souza et al. (2015). The Penman-Monteith method was used to estimate the ETo. Daily irrigation depths of $100 \%$ of ETc were applied in both experiments until 30 days after sowing. After that, water stress was applied in the second experiment, with reduction of irrigation to $50 \%$ of ETc.

After harvesting of dried ears, the total dry grain weight (TGW) in the useful plot area and the 100-grain weight $(100 \mathrm{~W})$ were determined. The dry grain yield (GY) was calculated by extrapolating the TGW to $\mathrm{Mg}_{\mathrm{g}} \mathrm{ha}^{-1}$, after correction of grain moisture to $15 \%$, according to equation 1.

$$
C G Y=\left(\frac{100-M C \%}{85}\right) N C G Y
$$

Where: CGY is the corrected grain yield; NCGY is the non-corrected grain yield; and MC $\%$ is the grain moisture content defined by the Digital Gehaka G650i moisture meter.

The cob percentage (Cob \%) was 
determined by the ratio between the total in a $5 \times 2$ factorial scheme, with four replications. dry grain weight (TGW) and the total dried The experimental plot consisted of four rows with ear weight (TEW) given by equation 2. five-meter length, composing the $5 \mathrm{~m}^{2}$ and $10 \mathrm{~m}^{2}$

$$
C o b \%=\left(\frac{T E W-T G W}{T E W}\right) 100
$$

The water use efficiency (WUE in $\mathrm{kg} \mathrm{ha}^{-1}$ $\mathrm{mm}^{-1}$ ) was calculated by dividing the grain yield (GY) by the irrigation depth (ID) applied, as per equation 3 (Santos Almeida et al., 2017).

$$
W U E=\frac{G Y}{I D}
$$

Where: GY is the grain yield $\left(\mathrm{kg} \mathrm{ha}^{-1}\right)$ and ID: cumulative irrigation depth ( $\mathrm{mm})$.

In both experiments, with and without water deficit, the plants were arranged in two spacings between rows $(0.5$ and $1.0 \mathrm{~m})$ and five plant populations $(20,000 ; 40,000 ; 60,000$; 80,000 ; and 10,000 plants $\mathrm{ha}^{-1}$ ), totaling 10 spacings between plants (Table 1). A randomized block design was used, with treatments arranged useful plot areas, with 0.5 and $1.0 \mathrm{~m}$ spacing, respectively. The central rows were used for the evaluations.

The statistical analysis of the experiments was carried out separately. Data obtained were submitted to Shapiro-Wilk test and Cochran's test for normality and homogeneity of variances, respectively. Once the basic requirements were fulfilled, data were submitted to the analysis of variance. Row spacing was considered a qualitative factor and compared through t-test. The effect of planting density was analysed through polynomial regression, according to Zimmermann (2004), with adoption of the reduced model composed of nine parameters containing individual linear and quadratic effects, and two-way interactions of first and second degree, as follows:

Where:

Table 1. Arrangement of spacing between plants in the sowing row in relation to the different plant

\begin{tabular}{|c|c|c|}
\hline \multirow{2}{*}{ PD } & $\mathrm{RS}(0.5 \mathrm{~m})$ & $\mathrm{RS}(1.0 \mathrm{~m})$ \\
\hline & \multicolumn{2}{|c|}{ Spacing between plants } \\
\hline 20,000 plants ha & $1.00 \mathrm{~m}$ & $0.50 \mathrm{~m}$ \\
\hline 40,000 plants ha & $0.50 \mathrm{~m}$ & $0.25 \mathrm{~m}$ \\
\hline 60,000 plants ha & $0.33 \mathrm{~m}$ & $0.16 \mathrm{~m}$ \\
\hline 80,000 plants ha & $0.25 \mathrm{~m}$ & $0.12 \mathrm{~m}$ \\
\hline 100,000 plants ha & $0.20 \mathrm{~m}$ & $0.10 \mathrm{~m}$ \\
\hline
\end{tabular}
densities (PD) and row spacing (RS) 


\section{$Y=b 0+b 1 A+b 2 A^{2}+b 3 B+b 4 B^{2}+b 5 A B+b 6 A B^{2}+b 7 A^{2} B+b 8 A^{2} B^{2}$}

\section{Results and Discussion}

$\mathrm{Y}$ is the dependent variable;

$\mathrm{b} 0$ is the regression constant;

$\mathrm{b} 1, \ldots \mathrm{b} 8$ are regression coefficients; and

$\mathrm{A}$ and $\mathrm{B}$ are independent variables, consisting of row spacing and plant density, respectively.

As a result of t-test application, the best model was selected, using the significances of each parameter, and accepting significance level until the $15 \%$ probability limit (Conagin \& Jorge, 1982). All statistical analyses were conducted with the use of R software - version 3.4.1.

The plant density (PD) significantly affected all parameters under evaluation, regardless of the irrigation depth applied. In the system where the irrigation level of $100 \%$ of ETc was applied, the row spacing (RS) affected, in an isolated manner, cob percentage ( $\mathrm{Cob}$ $\%$ ), grain yield (GY) and water use efficiency (WUE) (Table 2). In the presence of water deficit conditions, significant influence of RS could only be observed for grain yield (GY) and water use efficiency (WUE). In both water regimes, there was significant adjustment of the response surface for GY and WUE.

The increment of plant density produced a negative linear adjustment in the 100-grain

Table 2. Summary of the analysis of variance for effects of row spacing (RS) and planting density (PD) along the row on cob percentage (Cob \%), 100-grain weight (100W), grain yield (GY) and water use efficiency (WUE), in the AG - 1051 maize hybrid crop, cultivated under irrigation, with and without water deficit, in the municipality of Teresina, Piauí, Brazil.

\begin{tabular}{|c|c|c|c|c|c|c|c|c|c|}
\hline \multirow{2}{*}{$\begin{array}{l}\text { Source of } \\
\text { Variance }\end{array}$} & \multicolumn{5}{|c|}{ Without water deficit } & \multicolumn{4}{|c|}{ With water deficit } \\
\hline & $\mathrm{DF}$ & Cob $\%$ & $100 \mathrm{~W}$ & GY & WUE & Cob \% & $100 \mathrm{~W}$ & GY & WUE \\
\hline Block & 3 & $0.946^{\mathrm{NS}}$ & $4.677^{\mathrm{NS}}$ & $0.997^{\mathrm{NS}}$ & $0.058^{\mathrm{NS}}$ & $26.141^{\mathrm{NS}}$ & $0.786^{\mathrm{NS}}$ & $0.156^{\mathrm{NS}}$ & $0.022^{\mathrm{NS}}$ \\
\hline RS (m) & 1 & $13.98^{*}$ & $1.892^{\mathrm{NS}}$ & $3.312 *$ & $0.188 * *$ & $23.61^{\mathrm{NS}}$ & $0.306^{\mathrm{NS}}$ & $4.90 * *$ & $0.389 *$ \\
\hline PD (plants ha) & 4 & $164.59 * *$ & $38.34 * *$ & $13.56^{* *}$ & $0.772 * *$ & $256.57^{*}$ & $35.004 * *$ & $4.04 * *$ & $0.558 * *$ \\
\hline RS x PD & 4 & $4.266^{\mathrm{NS}}$ & $0.413^{\mathrm{NS}}$ & $0.960 *$ & $0.055^{*}$ & $5.923^{\mathrm{NS}}$ & $1.042^{\mathrm{NS}}$ & $0.851^{*}$ & $0.117 *$ \\
\hline Residue & 27 & 3.199 & 4.180 & 0.304 & 0.017 & 44.341 & 0.2316 & 0.188 & 0.026 \\
\hline Total & 39 & & & & & & & & \\
\hline CV \% & & 8.55 & 6.8 & 9.24 & 9.17 & 25.52 & 7.87 & 11.68 & 11.67 \\
\hline
\end{tabular}


weight (100W), with a more significant reduction observed in the regime with water deficit of $50 \%$ of ETo (Figure 1). According to Fumagalli et al. (2017), after flowering, the flow of photoassimilates in the plant is primarily directed to grain filling. The increment of plant density increases the competition between individual plants for water, light and nutrients, thus reducing the availability of photoassimilates to meet grainfilling demand and for maintenance of other plant structures. There is an acceleration of leaf senescence, associated with water deficit, which may have shortened the grain filling period.

Poor grain formation had an effect on cob percentage in relation to the total ear mass. It was observed that the increment of planting density (Figure 2A) produced a linear increase in the cob percentage, with an increment of $5.49 \%$ in the 1.0 $\mathrm{m}$ spacing (Figure 2B). This can be explained as a result of increase of plant density and reduction of spacing in the row, which implies in higher intraspecific competition, thus reducing the production of photoassimilates for grain filling and, consequently, increasing cob percentage (Sangoi et al., 2019).

The adjustments of response surfaces show that these results had significant impact on grain yield (GY). In full irrigation regime (Figure 3 ), the combination between the $0.5 \mathrm{~m}$ row spacing and planting density of 72,000 plants ha $^{-1}$ provided a maximum productivity of $7.2 \mathrm{Mg}$ $\mathrm{ha}^{-1}$. Under water deficit condition, a maximum productivity of $4.8 \mathrm{Mg} \mathrm{ha}^{-1}$ was reached in the combination between the $0.5 \mathrm{~m}$ row spacing and density of 67,000 plants ha ${ }^{-1}$ (Figure 4). The increase of grain yield as a function of the increment in plant population can be explained by the increase of the number of plants, which

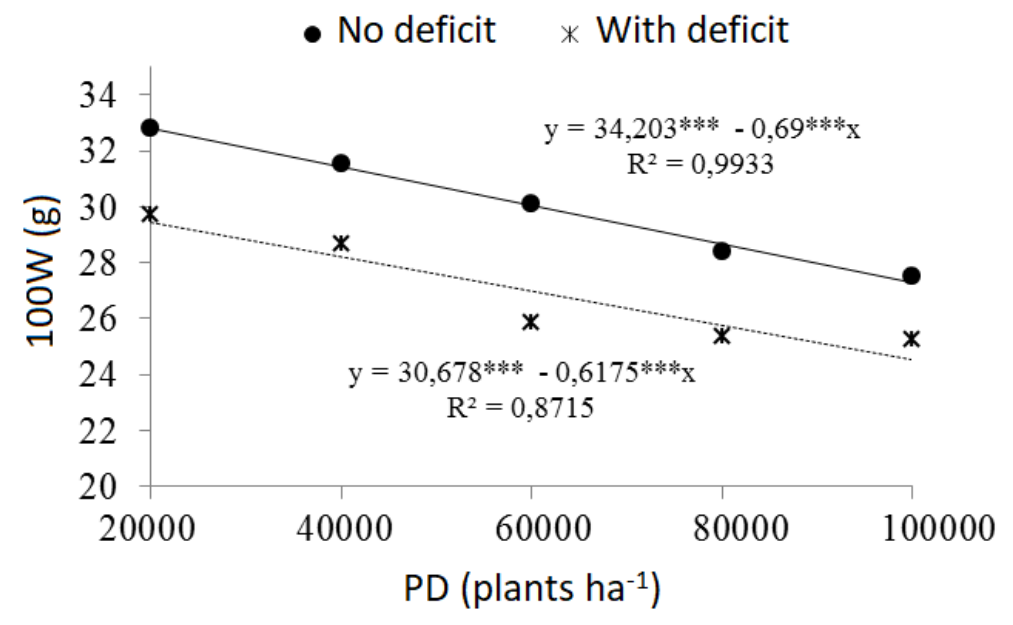

Figure 1. 100-grain weight of double-cross maize hybrid AG-1051, irrigated with and without water deficit, as a function of different planting densities (PD), in Teresina, PI, Brazil. Significance: '***' 0.001 ; '**'0.01; '*’'0.05; ‘’’ 0.1 . 
A

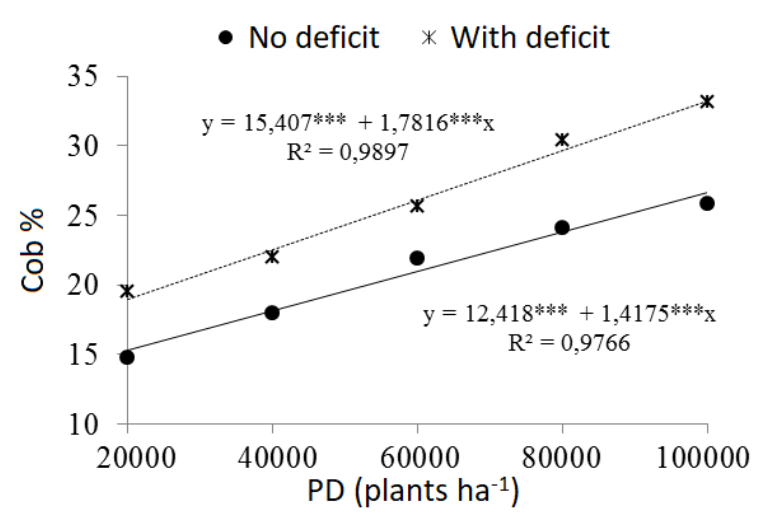

B

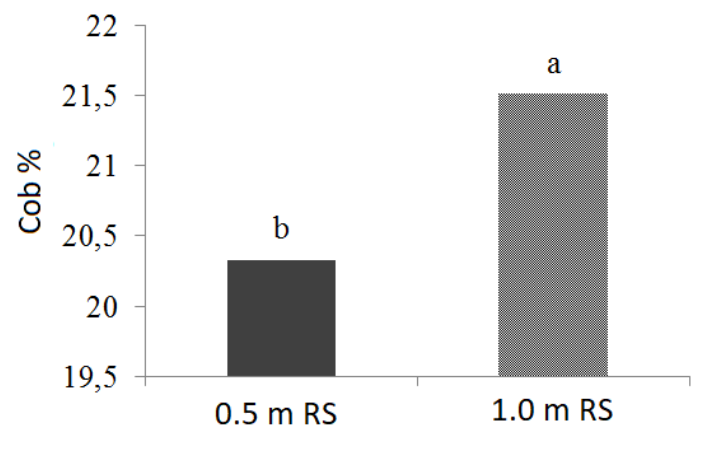

Figure 2. Cob percentage of double-cross maize hybrid AG-1051, irrigated with and without water deficit, as a function of different row spacing (RS) and planting densities (PD), in Teresina, PI, Brazil. Significance: ‘***’ 0.001 ; ‘**’ 0.01 ; ‘*’ 0.05 ; ‘.’ 0.1 .

Same letters in the columns do not differ from one another by t-test at a $5 \%$ probability.

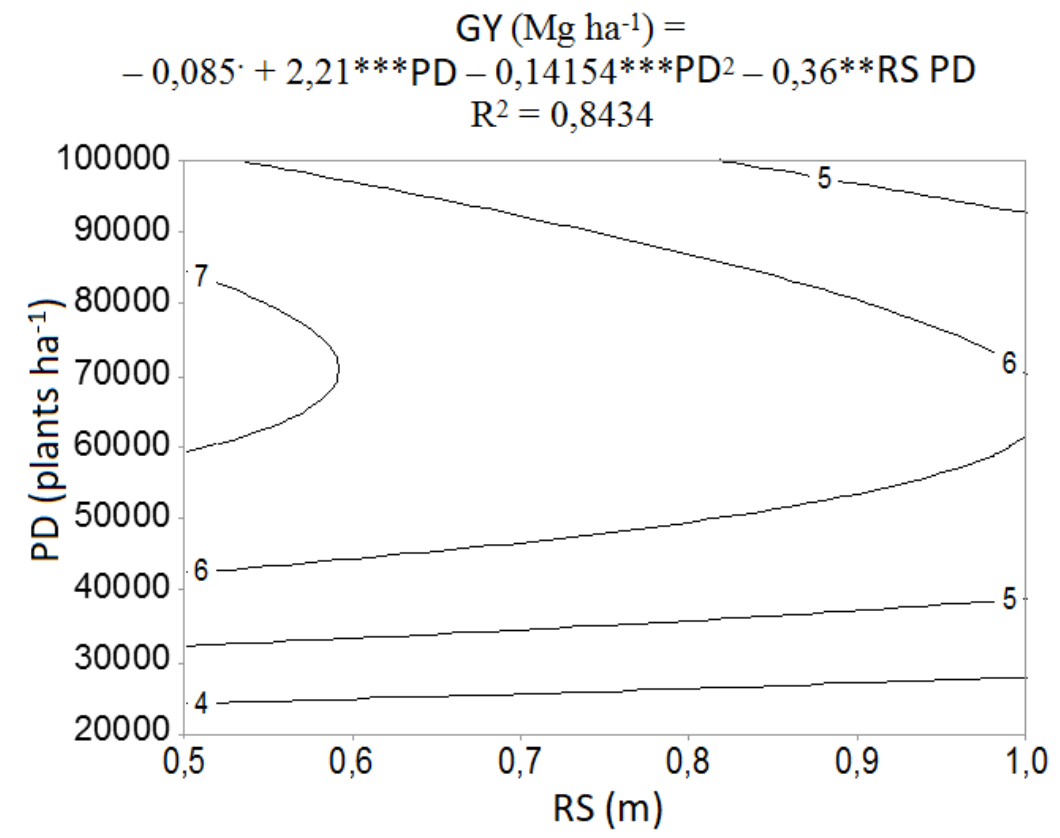

Figure 3. Grain yield (GY) of double-cross maize hybrid AG-1051, irrigated without water deficit, as a function of different row spacing (RS) and planting densities (PD), in Teresina, PI, Brazil.

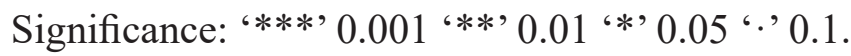


promotes the increment of the number of ears per area unit, thus resulting in compensation of the productivity until maximum point (Foloni et al., 2014).

Takasu et al. (2014) and Pereira et al. (2018) also obtained linear increment in maize grain yield until the population of 100,000 and 82,500 plants $^{-1} \mathrm{a}^{-1}$, respectively, while Sangoi et al. (2013) and Fumagalli et al. (2017) observed quadratic behavior, with maximum yield achieved in the population of 75,000 and 60,000 plants ha ${ }^{-1}$, respectively.

After reaching the maximum point, the reduction of productivity in higher planting densities is explained by the morphophysiological alterations observed throughout this work. The increment of planting density increases the competition between individual plants for water, light and nutrients, stimulating the apical dominance and reducing the availability of photoassimilates to meet grain-filling demand and for maintenance of other plant structures (leaves and culm). The lower photosynthetic activity of the leaves, caused by the occurrence of shading in crops with high plant densities and smaller row spacing, reduces the supply of carbohydrates to the roots, which is critical for the absorption of nutrients. This series of factors accelerate leaf senescence and shorten the grain-filling period, causing reduction of crop productivity (Kuneski et al., 2017; Fumagalli et al., 2017).

Under water deficit conditions, there was a reduction in the maximum grain yield of $33.33 \%$. Nascimento et al. (2017), when assessing the

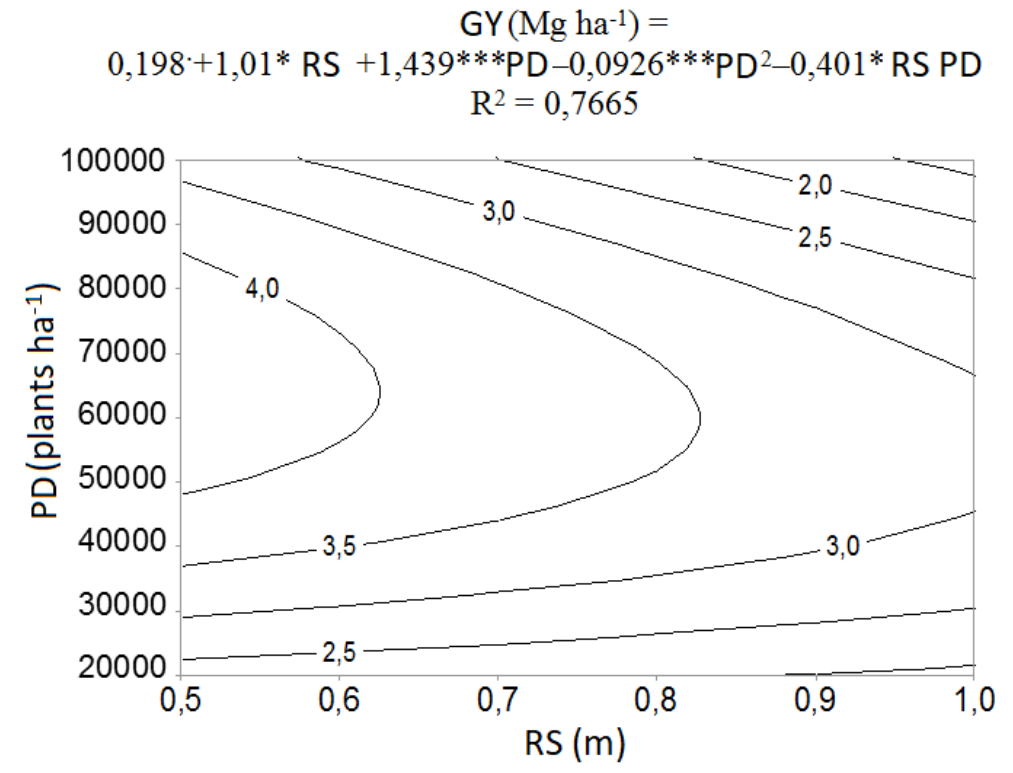

Figure 4. Grain yield (GY) of double-cross maize hybrid AG-1051, irrigated with water deficit, as a function of different row spacing (RS) and planting densities (PD), in Teresina, PI, Brazil. Significance: ' $* * * ’ 0.001^{\text {'**’ }} 0.01^{\text {'*’ }} 0.05^{\prime} \cdot$ ’ 0.1 . 
effect of different irrigation depths in maize crop in Teresina, observed that lower water depths provided lower grain yield.

According to Bergamaschi et al. (2014), maize presents great sensitivity to water deficit from the tasseling stage to the beginning of grain filling. High plant densities, associated with water deficit, increase the intraspecific competition for resources from the environment, with possible occurrence of morphological changes in growth, chlorophyll content, photosynthesis, and consequently in grain yield (Diniz et al., 2018).

With regard to water use efficiency
(WUE), the adjustment of the response surface shows that the application of the total water depth of $419 \mathrm{~mm}$ provided maximum WUE of $1.70 \mathrm{~kg} \mathrm{~m}^{-3}$ in the combination of the $0.5 \mathrm{~m}$ row spacing and density of 70,000 plants $\mathrm{h}^{-1}$ (Figure 5). When the $268 \mathrm{~mm}$ water depth is applied, there is a reduction in water use efficiency, with a maximum point of $1.54 \mathrm{~kg} \mathrm{~m}^{-3}$ reached in the combination between planting density of 67,000 plants $\mathrm{ha}^{-1}$ and $0.5 \mathrm{~m}$ row spacing (Figure 6). These results demonstrate that, under optimal conditions of water availability, maize plants are capable of using water more efficiently at higher

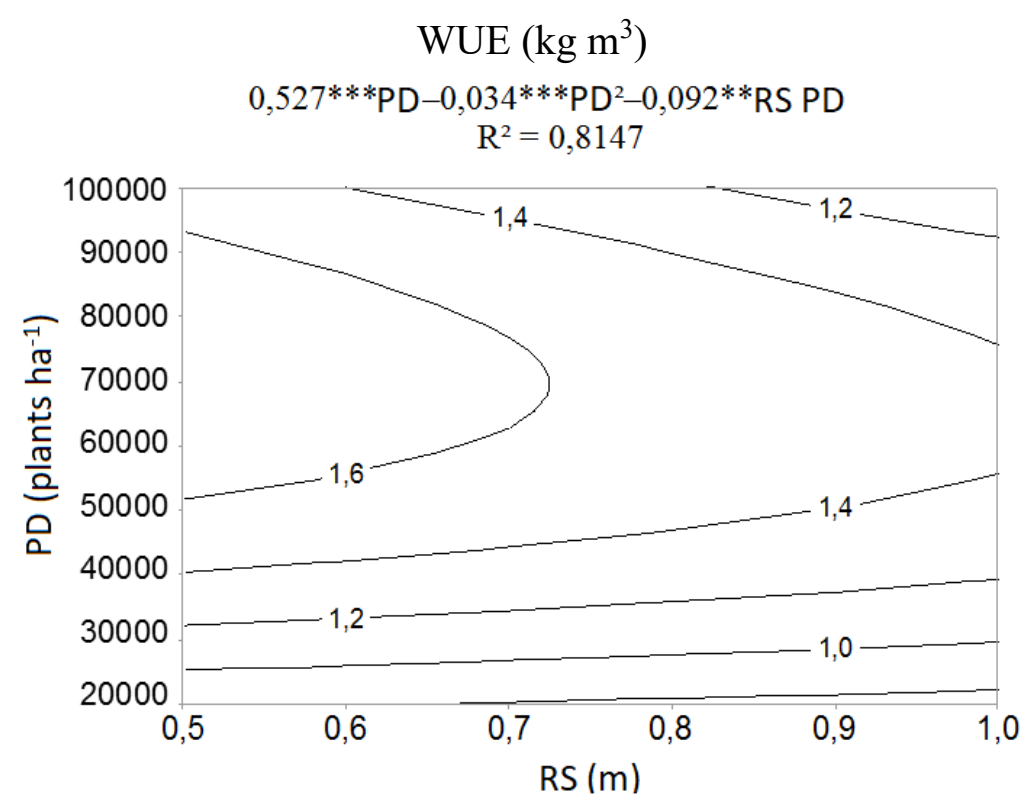

Figure 5. Water use efficiency (WUE) in the double-cross maize hybrid AG-1051 crop, irrigated without water deficit, as a function of different row spacing (RS) and planting densities (PD), in Teresina, PI, Brazil. Significance: ‘***’ 0.001 '**’ 0.01 '*’ 0.05 ' 0.1 . 


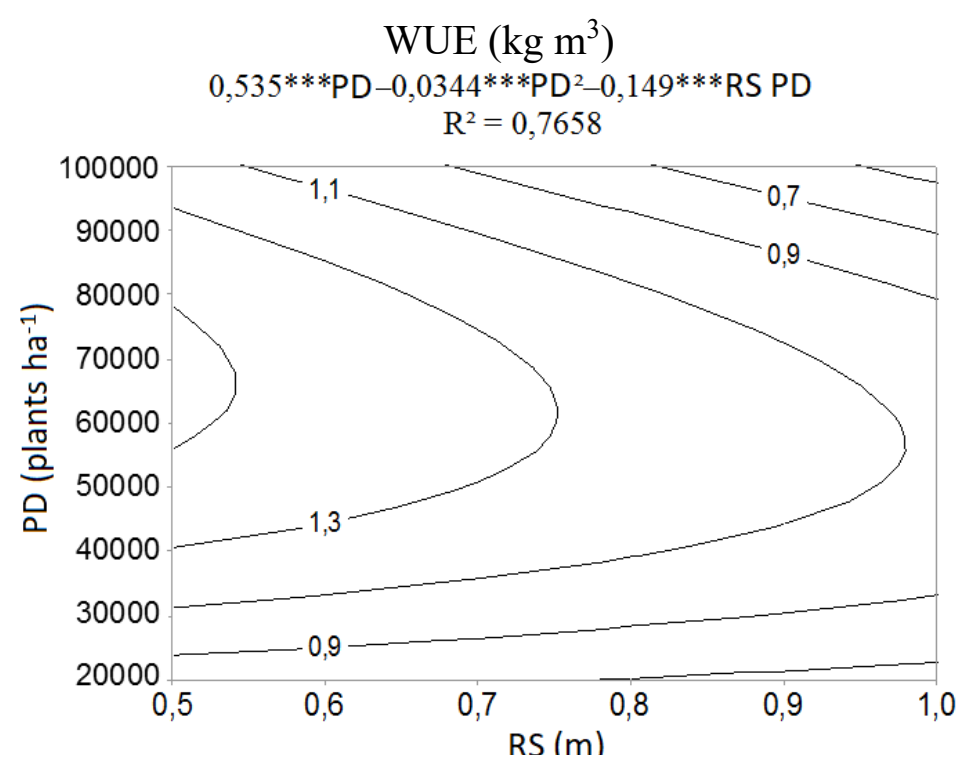

Figure 6. Water use efficiency (WUE) in the double-cross maize hybrid AG-1051 crop, irrigated with water deficit, as a function of different row spacing (RS) and planting densities (PD), in Teresina, PI, Brazil. Significance: '***’ $0.001^{\text {'*** }} 0.01^{\text {‘*’ }} 0.05^{\prime} \cdot$ ’ 0.1 .

planting density. Nascimento et al. (2017), when assessing different irrigation depths and physiological and productive characteristics of maize, obtained lower WUE values $\left(0.68 \mathrm{~kg} \mathrm{~m}^{-3}\right.$ and $0.64 \mathrm{~kg} \mathrm{~m}^{-3}$ ) with application of water depths lower than $50 \%$ of ETo.

\section{Conclusions}

The increment of planting density causes increase of cob percentage in relation to grain weight and reduction in 100-grain weight.

The plant arrangement that maximizes maize grain yield is the combination of 72,000 plants ha ${ }^{-1}$, with $0.5 \mathrm{~m}$ row spacing, under full irrigation conditions.
Under water deficit conditions, the arrangement that maximizes maize grain yield is the combination of 67,000 plants ha ${ }^{-1}$, with $0.5 \mathrm{~m}$ row spacing.

\section{Acknowledgements}

To Embrapa Meio-Norte for financing the project; M.W. L. Carvalho thanks CAPES (Coordination for the Improvement of Higher Education Personnel) for the $\mathrm{PhD}$ scholarship.

\section{References}

ACOMPANHAMENTO DA SAFRA BRASILEIRA [DE] GRÃOS: safra 2019/2020: segundo levantamento. Brasília, DF: Conab, v. 7 , nov. 2019.25 p. 
BASTOS, E. A.; ANDRADE JÚNIOR, A. S. Boletim agrometeorológico do ano de 2018 para o Município de Teresina, PI. Teresina: Embrapa Meio-Norte, 2019. (Embrapa MeioNorte, Documentos, 266).

BEN, L. H. B.; PEITER, M. X.; ROBAINA, A. D.; PARIZI, A. R. C.; SILVA, G. U. D. Influence of irrigation levels and plant density on "second-season" maize. Revista Caatinga, v. 29, n. 3, p. 665-676, 2016. DOI: 10.1590/1983-21252016v29n317rc.

BERGAMASCHI, H; MATZENAUER, R. O milho e o clima. Porto Alegre: Emater-RS: Ascar, 2014. 11 p.

CARDOSO, M.J.; RIBEIRO, V.Q.; MELO, F.B. Performance de cultivares de milho-verde no município de Teresina, Piauí. (Embrapa MeioNorte-Comunicado Técnico, 227), Teresina, 2011.

CONAGIN, A.; JORGE, J. P. N. Delineamento $(1 / 5)(5 \times 5 \times 5)$ em blocos. Bragantia, v. 41, n. 1, p. $155-168$, 1982. DOI: 10.1590/S000687051982000100016 .

CUNHA, B. A. D.; NEGREIROS, M. M. D.; ALVES, K. A.; TORRES, J. P. Influência da época de semeadura na severidade de doenças foliares e na produtividade do milho safrinha. Summa Phytopathologica, v. 45, n. 4, p. 424-427, 2019. DOI: $10.1590 / 0100-5405 / 188038$
DINIZ, R. P.; VON PINHO, I. V.; PANIAGO, B. D. C.; VON PINHO, E. V. D. R.; SANTOS, H. O.; VON PINHO, R. G.; CALDEIRA, C. M. Qualidade fisiológica e expressão de alfa-amilase em sementes de milho produzidas em condições de estresse salino e hídrico. Revista Brasileira de Milho e Sorgo, v. 17, n. 1, p. 37-48, 2018. DOI: 10.18512/1980-6477/rbms.v17n1p37-48.

FOLONI, J.S.S.; CALONEGO, J.C.; CATUCHI, T.A.; BELlEGGIA, N.A.; TIRITAN, C.S.; BARBOSA, A.D.M. Cultivares de milho em diferentes populações de plantas com espaçamento reduzido na safrinha. Revista Brasileira de Milho e Sorgo, v. 13, n. 3, p. 312 325, 2014. DOI: 10.18512/1980-6477/rbms. v13n3p312-325.

FUMAGALLI, M.; MACHADO, R.A.F.; FIORINI, I.V.A.; PEREIRA, C.S.; HÉLCIO, L.P.M.P.E.; PEREIRA, D. Desempenho produtivo do milho híbrido simples em função de espaçamentos entre fileiras e populações de plantas. Revista Brasileira de Milho e Sorgo, v. 16, n. 3, p. 425-438, 2017. DOI: 10.18512/19806477/rbms.v16n3p426-439

KUNESKI, H. F.; LEOLATO, L. S.; SANGOI, L.; COELHO, A. E.; DURLI, M. M.; PANISON, F. Regulador de crescimento e características morfológicas do milho em diferentes densidades de plantas e épocas de semeadura. Revista da 14a Jornada de Pós-Graduação e PesquisaCongrega Urcamp, p. 2497-2512, 2017. 
MARWEIN, M. A.; CHOUDHURY, B. Características agronômicas da planta e U.; CHAKRABORTY, D.; KUMAR, M.; produtividade da silagem de milho submetido a DAS, A.; RAJKHOWA, D. J. Response of water deficit regime and soil amelioration on evapotranspiration loss and water use efficiency of maize (Zea mays L.) in subtropical northeastern Himalayas. International Journal of Biometeorology, v. 61, n. 5, p. 845-855, 2017. DOI: $10.1007 / \mathrm{s} 00484-016-1262-4$.

MELO, F. de B.; ANDRADE JÚNIOR, A. S.; PESSOA, B. L. O. Levantamento, zoneamento e mapeamento pedológico detalhado da área experimental da Embrapa Meio-Norte em Teresina, PI. Teresina: Embrapa Meio-Norte, 2014. (Embrapa Meio-Norte-Documentos, 231).

MURÁNYI, E. Effect of plant density and row spacing on maize (Zea mays L.) grain yield in different crop year. Columella-Journal of Agricultural and Environmental Sciences, v. 2, n. 1, p. 57-63, 2015. DOI: 10.18380/SZIE. COLUM.2015.1.57.

NASCIMENTO, F.N.; BASTOS, E.A.; CARDOSO, M.J. Desempenho da produtividade de espigas de milho verde sob diferentes regimes hídricos. Revista Brasileira de Milho e Sorgo, v. 16, n. 1, p. 94-108, 2017. DOI: 10.18512/19806477/rbms.v16n1p94-108.

PEREIRA, L.B.; MACHADO, D.S.; ALVES FILHO, D.C.; BRONDANI, I.L.; DA SILVA, V.S.; ARGENTA, F.M.; BORCHATE, D. estratégias de manejo hídrico. Revista Brasileira

SANGOI, L.; ZANIN, C. G.; SCHMITT, A.; VIEIRA, J. Senescência foliar e resposta de híbridos de milho liberados comercialmente para cultivo em diferentes épocas ao adensamento. Revista Brasileira de Milho e Sorgo, v. 12, n. 1, p. 21-32, 2013. DOI: 10.18512/1980-6477/rbms. v12n1p21-32.

SANGOI, L.; SCHMITT, A.; DURLI, M. M.; LEOLATO, L. S.; COELHO, A. E.; KUNESKI, H. F.; OLIVEIRA, V. L. Estratégias de manejo do arranjo de plantas visando otimizar a produtividade de grãos do milho. Revista Brasileira de Milho e Sorgo, v. 18, n. 1, p. 47-60, 2019. DOI: 10.18512/1980-6477/rbms. v18n1p47-60.

SANTOS ALMEIDA, A. C.; BONIFÁCIO, J.; PUSCH, M.; OLIVEIRA, F. C.; GESEINHOFF, L. O.; BISCARO, G. A Produtividade e eficiência de uso da água em milho cultivado com diferentes estategias de manjo hidrico. Revista Brasileira SALES, R.A. LOUZADA, J. M.; OLIVEIRA, E. C.; PINHEIRO M. A. B. Estimativa das necessidades hídricas do milho cultivado nas condições edafoclimáticas de São Mateus-ES. Enciclopédia Biosfera, Goiânia, v. 13, n. 23, p. 598-609, 2016. 
de Agricultura Irrigada, v. 11, n. 3, p. 1448- THORNTHWAITE, C. W.; MATHER, J. R. The 1457, 2017.

water balance. Centerton, $\mathrm{NJ}$ : Drexel Institute of Technology, 1955. 104 p. (Publications in

SOUSA, R. S.; BASTOS, E. A.; CARDOSO, M. Climatology, v. 8, n. 1).

J.; RIBEIRO, V. Q.; BRITO, R. R. Desempenho produtivo de genótipos de milho sob déficit hídrico. Revista Brasileira de Milho e Sorgo, v. 14, n. 1, p. 49-60, 2015. DOI: 10.18512/19806477/rbms.v14n1p49-60.

UNITED STATES DEPARTMENT OF AGRICULTURE - USDA. Grain: world markets and trade. Whashington, 2020. (Circular Series).

ZIMMERMANN, F. J. P. (Ed.). Estatística SOUZA, L. S. B.; MOURA, M. S. B. aplicada à pesquisa agrícola. Santo Antônio de de; SEDIYAMA, G. C.; SILVA, T. G. F. Goiás: Embrapa Arroz e Feijão, 2004. 402p.

da. Requerimento hídrico e coeficiente de cultura do milho e feijão-caupi em sistemas exclusivo e consorciado. Revista Caatinga, v. 28, n. 4, p. 151-160, 2015. DOI: $10.1590 / 1983-21252015 \mathrm{v} 28 \mathrm{n} 417 \mathrm{rc}$.

TAKASU, A.T.; RODRIGUES, R.A.F.; GOES, R.J.; ARF, O.; HAGA, K.I. Desempenho agronômico do milho sob diferentes arranjos populacionais e espaçamento entrelinhas. Agrarian, v. 7, n. 23, p. 34-41, 2014. 